\title{
Efficacy of organomineral fertilizer and un-amended compost on the growth and yield of watermelon (Citrullus lanatus Thumb) in Ilorin Southern Guinea Savanna zone of Nigeria
}

\author{
James Adebayo Ojo • Adebayo Abayomi Olowoake • \\ Abiodun Obembe
}

Received: 23 July 2013/Accepted: 25 August 2014/Published online: 17 September 2014

(C) The Author(s) 2014. This article is published with open access at Springerlink.com

\begin{abstract}
Background Over the years, the use of organic materials in farming has reduced due to the increase in the use of chemical fertilizers which are rich in readily available plant nutrients. Intensive use of inorganic fertilizers may have depressing effect on yield of watermelon. Field experiment was conducted at the Teaching and Research Farm, Kwara State University Malete, Kwara State, Nigeria, to study the effects of different rates of Organomineral fertilizer Grade A, un-amended compost Grade B and NPK mineral fertilizer on the growth and yield of Citrullus lanatus.

Results There were significant differences $(P<0.05)$ among the treatments in relation to vine length, number of leaves, average weight of fruits and yield. NPK at $200 \mathrm{~kg} /$ ha had the highest vine length of $294.67 \mathrm{~cm}$ followed by organomineral fertilizer Grade A applied at $2.5 \mathrm{t} / \mathrm{ha}$ which had the value of $268.0 \mathrm{~cm}$. Un-amended compost Grade B at $1.5,2.0$ and $2.5 \mathrm{t} / \mathrm{ha}$ had vine length values of 257.7, 259.0 and 259.7, respectively. All the fertilizer treatments significantly $(P<0.05)$ had higher number of leaves than control. The highest fruit yield of watermelon (36.7 t/ha) was obtained from organomineral fertilizer Grade A at $2.5 \mathrm{t} / \mathrm{ha}$ and NPK.
\end{abstract}

\footnotetext{
J. A. Ojo $(\bowtie) \cdot$ A. A. Olowoake

Department of Crop Production, Kwara State University,

Malete, Kwara State, Nigeria

e-mail: james.ojo@kwasu.edu.ng

A. A. Olowoake

e-mail: aolowoake@yahoo.com
}

\section{A. Obembe}

Department of Biosciences and Biotechnology,

Kwara State University, Malete, Kwara State, Nigeria

e-mail: abiodun.obembe@kwsu.edu.ng
Conclusion From this study, the use of organomineral fertilizer in the cultivation of watermelon could be used as alternative to mineral fertilizer, although cost effective but difficult to procure and cannot substantially redress the physical fragility of the soil. It is recommended that organomineral fertilizer Grade $\mathrm{A}$ at $2.5 \mathrm{t} / \mathrm{ha}$ be adopted for watermelon cultivation in the study area.

Keywords Organomineral - Compost - Watermelon · Yield

\section{Background}

Watermelon (Citrullus lanatus) belong to the family $\mathrm{Cu}-$ curbitaceae, it is a vine-like (scrambler and trailer) flowering plant that originated from Southern Africa. It is one of the most widely cultivated crops in the world with a global production of 89.9 million mega grams in 2002 (FAO, 2003, Huh et al. 2008). In Nigeria, this fruit crop is mostly cultivated in the northern part because it is a warmth-loving plant and this makes its production seasonal in the southern part of the country (Charles 2005). Its global consumption is greater than that of any other cucurbit. According to Adeoye et al. (2007) and Oguntola (2006), watermelon is the most preferred among five other exotic vegetables examined in Ibadan Metropolis of Oyo State, Nigeria. Tropical soils are beset with the problems of acidity, low nutrient contents, nutrients imbalance and soil erosion. In order to obtain high yield of watermelon, it is necessary to augment the nutrient status of the soil to meet the crop's need. One of the ways of increasing the nutrient status is by boosting the soil nutrient content either with the use of organic materials such as poultry manure, animal waste, and compost or with inorganic fertilizers (Dauda 
et al. 2005). Watermelon is a heavy feeder on nitrogen and therefore requires application of $\mathrm{N}$ to boost its production. Most Nigerian soils have low nitrogen and it is usually supplemented with $\mathrm{N}$ fertilizer and the importance of this has increased over the years. However, the problem associated with the continuous use of chemical fertilizer is that while it can lead to high crop yield; it may cause pollution of ground water after crop harvest (Gordon et al. 1993), and have adverse effects on plant quality. Continuous dependence on chemical fertilizers may be accompanied by a decline in soil organic matter content, increased soil acidity, degradation of soil physical properties and increased rate of erosion due to instability of soil aggregates (Adeoluwa and Adeogun 2010).

The use of mineral fertilizer by farmers is limited because of scarcity, high costs and basic disadvantages in apparent inability to substantially redress the physical fragility and chemical deterioration of the soil (Adeniyan and Ojeniyi 2005). This necessitates research on the use of organic wastes that are cheap, readily available and environmentally friendly as fertilizers. One of the ways of improving soil fertility is by maintaining its organic matter. This is possible through the use of organic sources of fertilizer. Research has shown that organic based fertilizers are less leached into ground water than the chemical fertilizer (Sridhar and Adeoye 2003). Organomineral fertilizer appears to be reliable organic source of nitrogen needed for growing watermelon. Organomineral fertilizer is a lowinput technology of improving the nutrient status of tropical soils for sustainable crop production. They combine the attributes of both organic and inorganic fertilizers (Ayeni 2008). Studies by Adeoye et al. (2008); Fagbola and Ogungbe (2007); Ojeniyi et al. (2009) recorded positive responses of maize and pepper to organomineral fertilizers. Makinde et al. (2010) recorded that the use of organomineral fertilizer enhanced better growth in Amaranthus cruentus. There is paucity of information on the use of organic fertilizer for the production of watermelon in Ilorin, Nigeria. This study was carried out to evaluate the effects of organomineral fertilizer, un-amended compost and NPK mineral fertilizer on the production of the melon in Ilorin, Southern Guinea Savanna zone of Nigeria.

\section{Materials and methods}

Field experiments were conducted on a loamy sand soil at the Teaching and Research Farm, Kwara State University (KWASU), Malete, Ilorin, Nigeria. Ilorin (latitude $08^{\circ}$ $71^{\prime} \mathrm{N}$ and longitude $04^{\circ} 44^{\prime} \mathrm{E}, 365 \mathrm{~m}$ above sea level) is in the southern Guinea savannah zone of North Central Nigeria. Prior to land preparation, soil samples from the top $0-15 \mathrm{~cm}$ depth were collected from the experimental site
Table 1 Proximate analysis of organomineral fertilizer Grade $\mathrm{A}$ and $\mathrm{B}$

Source: Aleshinloye Fertilizer Company, Ibadan, Nigeria

* $50 \mathrm{~kg}$ Grade A cost 12.5 USD, $50 \mathrm{~kg}$ Grade B cost 9.4 USD, $50 \mathrm{~kg}$ NPK 15-15-15 fertilizer cost 37.5 USD

(1 USD approximately N164 as at Dec 2013)

for laboratory analysis. The test crop used was Sugar baby variety of $C$. lanatus. Soils were amended with three fertilizer types: organomineral fertilizer Grade A, un-amended compost Grade B, NPK 15-15-15 and control (no soil additive). Grades A and B are commercial fertilizer products of Aleshinloye Fertilizer Plant, Ibadan, Oyo State, Nigeria. The results of the laboratory analyses of the fertilizers are summarized in Table 1. The treatments used were as follows: control (no soil additive)-(T0), organomineral fertilizer Grade A-1.5 t/ha (TA1), organomineral fertilizer Grade A-2.0 t/ha (TA2), organomineral fertilizer Grade $\mathrm{A}-2.5 \mathrm{t} / \mathrm{ha}$ (TA3), un-amended compost Grade $\mathrm{B}-1.5 \mathrm{t} / \mathrm{ha}$ (TB1), un-amended compost Grade B-2.0 t/ ha (TB2), un-amended compost Grade B-2.5 t/ha (TB3) and NPK 15-15-15 $200 \mathrm{~kg} / \mathrm{ha}$. The treatments (organic source at varying rates) were incorporated into the soil prior to sowing of watermelon seeds, while inorganic fertilizer was applied 2 weeks after planting. Pre-cropping chemical analysis of the experimental soil was carried out before land preparation (Table 2). The experiment was laid out in a randomized complete block design with three replications. Three seeds of watermelon were sown per hole with intra and inter row spacing of $75 \times 90 \mathrm{~cm}$ and about 1 in. deep, thinned to one seedling per stand 2 weeks after planting (WAP). Each plot contained 12 plants, four of which were randomly selected and tagged for data collection. The plot size was $3 \mathrm{~m} \times 3 \mathrm{~m}$ separated by $1 \mathrm{~m}$ gap between plots and between replicates covering an area of $341 \mathrm{~m}^{2}$. Weeds were controlled manually by hoeing and subsequently by hand pulling. Data collection started at 2 weeks after planting and the experiment was terminated at the eighth week after planting when the fruits were adjudged ripe enough haven attained full market weight. Growth parameters collected were: length of vines, number of leaves, number of days to $50 \%$ flowering, while data on 
Table 2 Physico-chemical properties of soil of teaching and research farm

\begin{tabular}{ll}
\hline Parameters & $\begin{array}{l}\text { Soil test } \\
\text { value }\end{array}$ \\
\hline $\mathrm{pH}$ & 6.5 \\
Organic carbon $(\mathrm{g} / \mathrm{kg})$ & 1.5 \\
Total nitrogen $(\mathrm{g} / \mathrm{kg})$ & 2.2 \\
P Mehlich $(\mathrm{mg} / \mathrm{kg})$ & 11.3 \\
Exchangeable bases & \\
(c mol/kg) & \\
$\mathrm{K}$ & 0.3 \\
$\mathrm{Mg}$ & 0.3 \\
$\mathrm{Na}$ & 0.7 \\
$\mathrm{Ca}$ & 1.1 \\
Extractable micronutrients & \\
$(\mathrm{c}$ mol//kg) & \\
$\mathrm{Fe}$ & 51.7 \\
$\mathrm{Zn}$ & 2.2 \\
$\mathrm{Mn}$ & 69.5 \\
$\mathrm{Cu}$ & 0.7 \\
Textural class $(\%)$ & \\
Sand & \\
$\mathrm{Silt}$ & 84.4 \\
$\mathrm{Clay}$ & 9.4 \\
Textural class & 6.2 \\
\hline
\end{tabular}

average weight of fruits and yield were collected at harvesting. Data collected were analyzed using analysis of variance (ANOVA), while significant means were separated using Tukey's HSD test at $5 \%$ level of probability.

\section{Results and discussion}

The results of the soil analysis are presented in Table 2 . The soil was loamy sand and slightly acidic. However, the values of $\mathrm{N}, \mathrm{P}$ and $\mathrm{K}$ were below the critical values of the nutrients in the soil of Guinea Savanna (Aduloju 2004; Ayodele 1983), these relatively low level of major nutrients signify the need for augmentation to enhance the optimal performance of $C$. lanatus. The mean vine length of the watermelon, variety sugar baby as affected by different rates of fertilizers at 2, 4, 6 and 8 WAP are shown in Table 3. Vine length increased as the growing period increased. NPK had significantly $(P<0.05)$ highest vine length compared with the other treatments throughout the sampling period. Organomineral fertilizer Grade A at $2.5 \mathrm{t} /$ ha (TA3) came second and it was significantly better than un-amended compost Grade B (TB1, TB2 and TB3), respectively. The highest vine length obtained from NPK treatment may probably due to faster release of nutrient contents of NPK than those of other fertilizers. Similar
Table 3 Effects of organic fertilizer and NPK application on watermelon vine length after different growth times (weeks)

\begin{tabular}{lllll}
\hline Treatment & \multicolumn{4}{l}{ Vine length $(\mathrm{cm})$} \\
\cline { 2 - 5 } & $2 \mathrm{WAP}$ & $4 \mathrm{WAP}$ & $6 \mathrm{WAP}$ & $8 \mathrm{WAP}$ \\
\hline T0 & $12.0 \mathrm{~d}$ & $52.7 \mathrm{~d}$ & $96.0 \mathrm{e}$ & $134.0 \mathrm{e}$ \\
TA1 & $15.2 \mathrm{~cd}$ & $74.7 \mathrm{c}$ & $107.7 \mathrm{~d}$ & $253.0 \mathrm{~d}$ \\
TA2 & $17.5 \mathrm{bc}$ & $83.7 \mathrm{bc}$ & $116.0 \mathrm{c}$ & $258.0 \mathrm{~cd}$ \\
TA3 & $18.8 \mathrm{~b}$ & $87.0 \mathrm{ab}$ & $131.3 \mathrm{~b}$ & $268.0 \mathrm{~b}$ \\
TB1 & $17.2 \mathrm{bc}$ & $84.0 \mathrm{bc}$ & $103.3 \mathrm{~d}$ & $257.7 \mathrm{c}$ \\
TB2 & $17.2 \mathrm{bc}$ & $83.2 \mathrm{bc}$ & $106.3 \mathrm{~d}$ & $259.0 \mathrm{~cd}$ \\
TB3 & $18.5 \mathrm{~b}$ & $83.2 \mathrm{bc}$ & $107.7 \mathrm{~d}$ & $259.7 \mathrm{~cd}$ \\
NPK & $25.7 \mathrm{a}$ & $93.7 \mathrm{a}$ & $206.0 \mathrm{a}$ & $294.7 \mathrm{a}$ \\
\hline
\end{tabular}

T0 - control, TA1-organomineral fertilizer Grade A (1.5 t/ha), TA2-organomineral fertilizer Grade A (2.0 t/ha), TA3-organomineral fertilizer Grade A (2.5 t/ha), TB1-un-amended compost Grade B (1.5 t/ha), TB2-un-amended compost Grade B (2.0 t/ha), TB3- un-amended compost Grade B (2.5 t/ha), NPK-NPK 15-15-15 $(0.2 \mathrm{t} / \mathrm{ha})$, means followed by the same letter and within the same column are not significantly different using Tukey test at $P<0.05$

Table 4 Effects of organic fertilizers and NPK application on number of leaves of watermelon after different growth times (weeks)

\begin{tabular}{lllll}
\hline Treatment & \multicolumn{4}{l}{ Number of leaves } \\
\cline { 2 - 5 } & 2 WAP & 4 WAP & 6 WAP & 8 WAP \\
\hline T0 & $6.3 \mathrm{a}$ & $24.3 \mathrm{~d}$ & $72.0 \mathrm{~d}$ & $91.0 \mathrm{~d}$ \\
$\mathrm{TA} 1$ & $7.0 \mathrm{a}$ & $26.3 \mathrm{~cd}$ & $88.0 \mathrm{c}$ & $106.0 \mathrm{bc}$ \\
$\mathrm{TA2}$ & $6.3 \mathrm{a}$ & $26.7 \mathrm{bc}$ & $89.3 \mathrm{bc}$ & $106.7 \mathrm{~b}$ \\
TA3 & $6.7 \mathrm{a}$ & $29.3 \mathrm{a}$ & $92.7 \mathrm{a}$ & $108.6 \mathrm{a}$ \\
TB1 & $6.3 \mathrm{a}$ & $28.7 \mathrm{ab}$ & $91.3 \mathrm{ab}$ & $105.3 \mathrm{bc}$ \\
TB2 & $6.3 \mathrm{a}$ & $28.7 \mathrm{ab}$ & $91.3 \mathrm{ab}$ & $104.7 \mathrm{c}$ \\
TB3 & $6.3 \mathrm{a}$ & $28.7 \mathrm{ab}$ & $91.7 \mathrm{ab}$ & $105.0 \mathrm{c}$ \\
NPK & $7.0 \mathrm{a}$ & $30.7 \mathrm{a}$ & $93.3 \mathrm{a}$ & $109.7 \mathrm{a}$ \\
\hline
\end{tabular}

T0 - control, TA1 - organomineral fertilizer Grade A (1.5 t/ha), TA2organomineral fertilizer Grade A $(2.0 \mathrm{t} / \mathrm{ha})$, TA3 - organomineral fertilizer Grade A (2.5 t/ha), TB1-un-amended compost Grade B (1.5 t/ha), TB2 - un-amended compost Grade B (2.0 t/ha), TB3-unamended compost Grade B (2.5 t/ha), NPK-NPK 15-15-15 (0.2 t/ ha), Means followed by the same letter and within the same column are not significantly different using Tukey test at $P<0.05$

reports have been made on faster nutrient release from inorganic fertilizers compared to organic nutrients sources when used for the production of vegetables, cereal and tree crops (Ainika et al. 2012; Adeoye et al. 2008; Ipinmoroti et al. 2006). Table 4 shows the number of leaves of watermelon as affected by different rates of fertilizer at 2 , 4, 6 and 8 WAP. At 8 weeks after planting, the number of leaves obtained in plot treated with TA3 (108.6) and NPK (109.7) were not significantly different from each other, but significantly higher than control and other treatments. NPK and organomineral fertilizer Grade A (TA3) at $2.5 \mathrm{t} / \mathrm{ha}$ 
Table 5 Effects of organic fertilizer and NPK application on days to $50 \%$ flowering of watermelon

\begin{tabular}{ll}
\hline Treatment & Days to $50 \%$ flowering $(\mathrm{ns})$ \\
\hline T0 & 33.6 \\
TA1 & 33.3 \\
TA2 & 34.0 \\
TA3 & 33.6 \\
TB1 & 34.3 \\
TB2 & 34.7 \\
TB3 & 34.3 \\
TNPK & 33.6 \\
CV $(\%)$ & 2.31
\end{tabular}

T0-control, TA1-organomineral fertilizer Grade A (1.5 t/ha), TA2 - organomineral fertilizer Grade A (2.0 t/ha), TA3 - organomineral fertilizer Grade A (2.5 t/ha), TB1-un-amended compost Grade B (1.5 t/ha), TB2 - un-amended compost Grade B (2.0 t/ha), TB3 - un-amended compost Grade B (2.5 t/ha), NPK-NPK 15-15$15(0.2 \mathrm{t} / \mathrm{ha})$

Table 6 Effects of fertilizer types on the yield components of watermelon

\begin{tabular}{lll}
\hline Treatment & Average fruit weight $(\mathrm{kg})$ & Yield $(\mathrm{t} / \mathrm{ha})$ \\
\hline T0 & $1.5 \mathrm{~d}$ & $20.3 \mathrm{e}$ \\
TA1 & $2.2 \mathrm{bc}$ & $31.4 \mathrm{c}$ \\
TA2 & $2.5 \mathrm{ab}$ & $31.9 \mathrm{~b}$ \\
TA3 & $2.8 \mathrm{a}$ & $36.7 \mathrm{a}$ \\
TB1 & $1.9 \mathrm{~cd}$ & $29.4 \mathrm{~d}$ \\
TB2 & $1.9 \mathrm{~cd}$ & $29.5 \mathrm{~d}$ \\
TB3 & $1.9 \mathrm{~cd}$ & $29.7 \mathrm{~d}$ \\
NPK & $2.7 \mathrm{a}$ & $36.7 \mathrm{a}$ \\
\hline
\end{tabular}

T0 - control, TA1-organomineral fertilizer Grade A (1.5 t/ha), TA2 - organomineral fertilizer Grade A $(2.0 \mathrm{t} / \mathrm{ha})$, TA3 - organomineral fertilizer Grade A (2.5 t/ha), TB1—un-amended compost Grade B (1.5 t/ha), TB2—un-amended compost Grade B (2.0 t/ha), TB3 - un-amended compost Grade B (2.5 t/ha), NPK-NPK 15-15$15(0.2 \mathrm{t} / \mathrm{ha})$. Means followed by the same letter and within the same column are not significantly different using Tukey test at $P<0.05$

significantly enhanced the production of leaves than other treatments including control. The higher number of leaves of melon produced from TA3 could be due to enhancement of decomposition of the organic material and mineralization of nutrients especially $\mathrm{N}$ and $\mathrm{P}$ by the presence of mineral fertilizer in organomineral. This is supported by the work of Okunlola et al. (2011).

With respect to days to $50 \%$ flowering, Table 5 shows that there was no significant difference among the plots treated with varying levels of fertilizer, as the shortest day to flowering recorded was 33.3 days while the longest was 34.7 days. The effects of the fertilizers on the average fruit weight and yield are shown in Table 6. NPK and organomineral fertilizers used at various rates increased the average fruit weight and yield of watermelon. However, organomineral fertilizer (TA3) has shown a great influence on the yield components of watermelon. This supports the works of Babatola et al. (2002) and Ogunlade et al. (2011) who noted that the combination of organic and mineral fertilizers perform better on yield of vegetables. The lowest nutrients recorded by the control experiment might be the reason why the yield parameters were very low compared with other treatments.

\section{Conclusion}

This study showed that organomineral fertilizer Grade A at $2.5 \mathrm{t} / \mathrm{ha}$ gave the best performance among all other organomineral fertilizers used due to its impact on the growth and yield of watermelon. Given its superior responses, Grade A fertilizer applied at a rate of $2.5 \mathrm{t} / \mathrm{ha}$ could serve as alternative to mineral fertilizer. It is therefore reasonable to recommend the use of organomineral Grade A fertilizer $2.5 \mathrm{t} / \mathrm{ha}$ in the cultivation of watermelon.

Acknowledgments The financial assistance rendered by the Centre for Community Development, Kwara State University, Malete, in the conduct of this research is highly appreciated.

Conflict of interest The authors declare that they have no competing interests.

Authors' contributions J. A. Ojo carried out the field study, soil and plant analysis, and statistical analysis and helped draft the manuscript. A. A. Olowoake conceived the study, participated in its design and coordination, and helped draft the manuscript. A. Obembe participated in the design of the study, performed statistical analysis, and helped draft the manuscript. All authors read and approved the final manuscript.

Open Access This article is distributed under the terms of the Creative Commons Attribution License which permits any use, distribution, and reproduction in any medium, provided the original author(s) and the source are credited.

\section{References}

Adeniyan ON, Ojeniyi SO (2005) Effect of poultry manure, NPK 15-15-15 and combination of their reduced levels on maize growth and soil chemical properties. Nig Soil Sci 15:34-41

AdeOluwa OO, Adeogun OO (2010) Evaluation of feather as organic fertilizers on Amaranthus (Amaranthus caudatus). Proceedings of 1st Technical Workshop on Organic Agriculture Conference 6-8 September, 2010. Ladoke Akintola University of Technology, Ogbomoso, pp 16-19

Adeoye IB, Denton OA, Oladapo MO, Olufunmi OO, Okafor BN Ajetunmobi T (2007) Consumer preference and awareness for some exotic vegetables in Ibadan, Oyo State. In: Proceedings of 25 annual conference of the horticultural society of Nigeria, pp 228-233

Adeoye GO, Sridhar MKC, Adeoluwa OO, Oyekunle M, Makinde EA, Olowoake AA (2008) Comparative evaluation of organomineral fertilizer (OMF) and Mineral fertilizer (NPK) on yield 
and quality of maize (Zea mays (L) Moench). Niger J Soil Sci $18: 141-147$

Aduloju MO (2004) Acid extractable micronutrients (Mn and Zn) in selected soils of vegetables producing areas of Kwara State, Nigeria. Niger J Hortic Sci 9:116-199

Ainika JN, Amans EB, Olonitola CO, Okutu PC, Dodo EF (2012) Effect of organic and inorganic fertilizer on growth and yield of amaranthus caudatus L. in Northern Guinea Savanna of Nigeria. World J Eng Pure Appl Sci 2(2):26-30

Ayeni LS (2008) Integration of cocoa pod ash, poultry manure and NPK 20:10:10 fertilizer for soil fertility management Incubation study. Cont J Agron Niger 2:25-30

Ayodele OJ (1983) Soil fertility management for the production of fruits and vegetables in Southwestern Nigeria. Acta Hort 128:237-242

Babatola LA, Adebayo OB, Lawal OI (2002) Effects of different rates of poultry manure and NPK on performance of Celosia argentia. Proceedings of Horticultural Society of Nigeria, Ibadan. 14-19, May 2002, pp 54-56

Charles FA (2005) Watermelon breeder cucurbit breeding horticultural science retrieved Jul 17

Dauda SN, Aliyu L, Chiezey UF (2005) Effects of variety, seedling age and poultry manure on growth and yield of garden egg (Solanum gilo L.). The Nigerian Academic. Forum 9(1):88-95

Fagbola O, Ogungbe PN (2007) Growth and yield response of some maize cultivars to Organomineral fertilizer application in simulated degraded soil under greenhouse condition. Niger J Soil Sci 7: 87-93. FAO (2003) Agricultural Production: Primary crops. http://www.fao.org, pp 40-50

Gordon WB, Whitney DA, Raney RJ (1993) Nitrogen management in furrow irrigated, ridge tilled corn. J Prod Agric 6:213-217
Huh YC, Solmaz I, Sari N (2008) Morphological characterization of Korean and Turkish watermelon germplasm. Pitrat M (ed) Cucurbitaceae 2008, Proceedings of the 9 EUCARPIA meeting on genetics and breeding of Cucurbitaceae Avignon (France), May 21-24 2008, pp 327-333

Ipinmoroti RR, Adebowale LA, Ogunlade MO, Iremiren GO, Adeoye GO (2006) Effect of inorganic and organic nutrient sources on growth, dry matter yield and nutrient uptake of Coffee (Coffea canephora L) seedlings. Proceedings international coffee (ASIC) Conference, France, 13-19 September, 2006, pp 1196-1198

Makinde EA, Ayeni LS, Ojeniyi SO (2010) Morphological characteristics of amaranthus cruentus L. as influenced by Kola Pod Husk, organomineral and NPK Fertilizers in Southwestern Nigeria. NY Sci J 3(5):130-134

Ogunlade MO, Adeyemi EA, Ogunleti DO, Ibiyomi PS (2011) Effect of cocoa pod husk, urea fortified cocoa pod husk and NPK fertilizers on the growth and yield of Solanum macrocarpon. Int $\mathbf{J}$ Org Agric Res Dev 3:1-8

Oguntola S (2006) Watermelon; Hidden gem yet to be discovered. Nigerian Tribune. Thursday 13th, July

Ojeniyi SO, Ezekiel PO, Asawalam DO, Awo AO, Odedina SA, Odedina JN (2009) Root growth and NPK status of cassava as influences by oil palm bunch ash. Afr $\mathrm{J}$ Biotechnol 18:4407-4412

Okunlola AI, Adejoro SA, Fakanlu G (2011) Evaluation of some manure types for the growth and yield of watermelon in Southwestern Nigeria. Researcher 3(3):61-66

Sridhar MKC, Adeoye GO (2003) Organomineral fertilizer from urban wastes. Niger Field 68:91-111 